Joyful Learning Journal

\title{
HUBUNGAN KEBIASAAN BELAJAR DAN DISIPLIN BELAJAR DENGAN HASIL BELAJAR IPS
}

\section{Agil Setiawan $^{凶}$, Ali Sunarso}

Jurusan Pendidikan Guru Sekolah Dasar, Fakultas Ilmu Pendidikan, Universitas Negeri Semarang, Indonesia

\begin{tabular}{l}
\hline Info Artikel \\
\hline Sejarah Artikel: \\
Diterima Januari \\
$\mathbf{2 0 2 0}$ \\
Disetujui Februari \\
$\mathbf{2 0 2 0}$ \\
Dipublikasikan \\
Maret 2020 \\
\hline
\end{tabular}

Keywords: learning discipline, social studies learning outcomes, study habits

\begin{abstract}
Abstrak
Tujuan penelitian ini adalah untuk menguji hubungan kebiasaan belajar dan disiplin belajar dengan hasil belajar IPS siswa kelas IV SDN Gugus Sadewa Kecamatan Petanahan Kabupaten Kebumen. Penelitian ini adalah penelitian kuantitatif jenis korelasi. Teknik sampel yang digunakan adalah Proportional Random Sampling sebanyak 103 siswa. Teknik pengumpulan data menggunakan angket, dokumentasi, dan wawancara. Teknik analisis data dengan analisis statistik deskriptif dan analisis product moment. Hasil penelitian menunjukkan bahwa: (1) terdapat hubungan yang positif dan signifikan antara kebiasaan belajar dengan hasil belajar IPS, nilai ritung $=0,749$ dan termasuk kategori kuat serta berkontribusi sebesar $54,2 \%$; (2) terdapat hubungan yang positif dan signifikan antara disiplin belajar dengan hasil belajar IPS, nilai hitung $=0,777$ dan termasuk kategori kuat serta berkontribusi sebesar $57,6 \%$; (3) terdapat hubungan yang positif dan signifikan antara kebiasaan belajar dan disiplin belajar secara bersama-sama dengan hasil belajar IPS, nilai hitung $=0,790$ termasuk kategori kuat serta berkontribusi sebesar $62,3 \%$.
\end{abstract}

\section{Abstract}

The purpose of this research was to examine the correlation between study habits and learning discipline with social studies learning outcomes of $4^{\text {th }}$ grade students in Cluster Sadewa Elementary School Petanahan Kebumen. This is a quantitative research correlation design. The sample technique was proportional random sampling of 103 participants. Data collection technique were questionnaires, interview, and documentation. These data were analyzed by having descriptive statistic analyzed and product moment analyzed. The result of this research showed that (1) there was a positive and significant correlation between study habits and social studies learning outcomes, rount $=0.749$ which included in strong category and contribution of 54.2\%; (2) there was a positive and significant correlation between learning discipline and social studies learning outcomes, $r_{\text {count }}=0.777$ which included in strong category and contribution of 57.6\%; (3) there was a positive and significant correlation study habits and learning discipline toward social studies learning outcomes, $r_{\text {count }}=0.790$ which included in strong category and contribution of $62.3 \%$.

C 2020 Universitas Negeri Semarang

\footnotetext{
Alamat Korespondensi:

Desa Nampudadi, RT 05/ RW 03, Petanahan, Kebumen

E-mail: agilsetiawan576@gmail.com
}

ISSN 2252-6366 


\section{PENDAHULUAN}

Pendidikan mempunyai peran dalam meningkatkan kualitas sumber daya manusia serta upaya mencerdaskan kehidupan bangsa. Salah satu bagian penting dalam pendidikan adalah kurikulum. Kurikulum digunakan sebagai pedoman dalam proses pembelajaran. Sebagaimana tercantum dalam Peraturan Kementerian Pendidikan dan Kebudayaan Nomor 23 Tahun 2016 tentang Standar Penilaian yang menyatakan bahwa Pembelajaran adalah proses interaksi antar peserta didik, antara peserta didik dengan pendidik dan sumber belajar pada suatu lingkungan belajar.

Lingkungan belajar yang baik, juga akan ikut mempengaruhi hasil belajar siswa menjadi lebih baik pula. Menurut Wasliman (2007:158), hasil belajar yang dicapai peserta didik merupakan interaksi antara antara berbagai faktor yang mempengaruhi baik faktor internal maupun eksternal. Faktor internal merupakan faktor yang ada dalam diri peserta didik yang mempengaruhi kemampuan belajarnya meliputi: kecerdasan, minat dan perhatian, motivasi belajar, ketekunan, sikap kondisi fisik dan kesehatan, dan kebiasaan belajar. Kebiasaan belajar merupakan salah satu faktor internal yang dapat mempengaruhi hasil belajar. Menurut Aunurrahman (2014: 185), kebiasaan belajar merupakan perilaku belajar seorang yang telah tertanam dalam waktu yang relatif lama sehingga memberikan ciri dalam aktivitas belajar yang dilakukannya.

Kebiasaan belajar yang baik dan berlangsung secara terus menerus akan membentuk sikap disiplin dalam belajar. Daryanto (2013) berpendapat bahwa disiplin pada dasarnya adalah suatu kontrol diri dalam mematuhi aturan baik itu yang dibuat oleh diri sendiri, di dalam keluarga, lembaga pendidikan, masyarakat, maupun beragama.

Peneliti telah melakukan prapenelitian di SDN Gugus Sadewa menunjukkan bahwa siswa kurang antusias dalam mengikuti pembelajaran, konsentrasi dan keberanian siswa di dalam kelas masih kurang sehingga terdapat siswa yang pasif, terdapat siswa yang mencontek saat ulangan, terdapat siswa yang tidak mengumpulkan tugas tepat waktu, keterbatasan fasilitas belajar, terdapat siswa yang belum mempunyai kesadaran untuk belajar sendiri, sebagian siswa belum mempunyai jadwal belajar secara teratur. Apabila siswa tidak memiliki kebiasaan belajar dan disiplin belajar yang baik maka akan berdampak pada hasil belajar yang diperoleh. Berdasarkan data dokumentasi menunjukkan bahwa rata-rata di kelas IV SDN Gugus Sadewa ada 39\% dari 147 peserta didik yaitu
57 anak yang memperoleh nilai di bawah KKM.

Penelitian terdahulu yang relevan adalah penelitian yang dilakukan oleh Arina Ulfa Dwipa Hapsari tahun 2019 dengan judul "Hubungan Perhatian Orang Tua dan Disiplin Belajar Terhadap Hasil Belajar PPKn Siswa Kelas IV SD Gugus Tugu Muda Kota Semarang”. Jurnal penelitian internasional oleh Philomena Mukani Njoroge tahun 2014 menetapkan bahwa disiplin sangat penting untuk prestasi akademik di sekolah. Selanjutnya Penelitian yang dilakukan oleh Arne Piene tahun 2016 menunjukkan bahwa siswa dalam kurikulum modern belajar lebih baik melalui metode pengajaran mandiri daripada melalui metode konvensional. Tujuan dilaksanakan penelitian ini adalah sebagai berikut: (1) menguji hubungan antara kebiasaan belajar dengan hasil belajar IPS siswa kelas IV SDN Gugus Sadewa Kecamatan Petanahan Kabupaten Kebumen; (2) menguji hubungan antara disiplin belajar dengan hasil belajar IPS siswa kelas IV SDN Gugus Sadewa Kecamatan Petanahan Kabupaten Kebumen; (3) menguji hubungan kebiasaan belajar dan disiplin belajar secara bersama-sama dengan hasil belajar IPS siswa kelas IV SDN Gugus Sadewa Kecamatan Petanahan Kabupaten Kebumen.

\section{METODE PENELITIAN}

Penelitian ini merupakan penelitian kuantitatif jenis penelitian korelasi. Penelitian korelasi bertujuan untuk menemukan ada tidaknya suatu hubungan berupa eratnya hubungan serta berarti tidaknya hubungan tersebut (Arikunto, 2013). Subjek dalam peneltian ini adalah siswa kelas IV SDN Gugus Sadewa Kecamatan Petanahan Kabupaten Kebumen. Penelitian ini dilaksanakan di SDN Gugus Sadewa Kecamatan Petanahan Kabupaten Kebumen yaitu SDN Nampudadi, SDN Kebonsari, SDN Tresnorejo, SDN Podourip, SDN 1 Jatimulyo, SDN 2 Jatimulyo, SDN 2 Kritig.

Teknik pengambilan sampel adalah Proportional Random Sampling dengan sampel sebanyak 103 siswa. Variabel dalam penelitian ini terdiri atas dua variabel bebas dan satu variabel terikat. Variabel bebas adalah kebiasaan belajar dan disiplin belajar, sedangkan variabel terikat adalah hasil belajar IPS. Teknik pengumpulan data dengan angket, dokumentasi, dan wawancara. Angket digunakan untuk mengumpulkan data variabel kebiasaan belajar dan disiplin belajar sedangkan dokumentasi digunakan untuk mendapatkan data hasil belajar IPS. Sebelum instrumen penelitian digunakan, maka dilakukan uji coba. Selanjutnya peneliti menguji validitas dan reliabilitas instrumen tersebut. Teknik analisis data yang digunakan pada penelitian ini adalah: (1) uji prasyarat analisis meliputi uji normalitas, linieritas, dan multikolinieritas; (2) analisis statistik deskriptif; 
dan (3) analisis pengujian hipotesis menggunakan korelasi sederhana, korelasi ganda, uji F (signifikan), dan koefisien determinasi.

Hasil analisis statistik deskriptif digunakan untuk mendeskripsikan secara rinci setiap variabel penelitian. Pembahasan variabel menggunakan data kuantitatif, yaitu data yang diolah berbentuk angka atau skor yang kemudian ditafsirkan secara deskriptif. Pengkategorian data variabel kebiasaan belajar dan disiplin belajar dibedakan menjadi empat kategori yaitu sangat baik, baik, cukup baik, dan kurang baik (Widoyoko, 2017). Sedangkan pengkategorian data variabel hasil belajar IPS siswa dibedakan menjadi empat kategori yaitu sangat baik, baik, cukup, dan kurang (Permendikbud Nomor 56 tahun 2014).

\section{Hasil Analisis Deskriptif Kebiasaan Belajar (X1)}

Jumlah pernyataan dalam angket kebiasaan belajar terdiri atas 24 item. Kebiasaan belajar siswa kelas IV SDN Gugus Sadewa Kecamatan Petanahan Kabupaten Kebumen dapat dilihat pada tabel berikut:

Tabel 1. Kategori Kebiasaan Belajar

\begin{tabular}{|c|c|c|c|c|}
\hline Interval Skor & Kategori & Frekuensi & Presentase (\%) & Rata-Rata \\
\hline $82-100$ & Sangat Baik & 35 & $34 \%$ & \multirow{5}{*}{$\begin{array}{c}78 \\
\text { (Baik) }\end{array}$} \\
\hline $63-81$ & Baik & 62 & $60 \%$ & \\
\hline $44-62$ & Sedang & 6 & $6 \%$ & \\
\hline $25-43$ & Kurang & 0 & $0 \%$ & \\
\hline Jun & & 103 & $100 \%$ & \\
\hline
\end{tabular}

Sumber: Data penelitian yang diolah menggunakan Microsoft Excel 2013

\section{Hasil Analisis Deskriptif Disiplin Belajar (X2)}

Jumlah pernyataan dalam angket disiplin belajar terdiri atas 32 item. Disiplin belajar kelas IV SDN Gugus Sadewa Kecamatan Petanahan Kabupaten Kebumen dapat dilihat pada tabel berikut:

Tabel 2. Kategori Disiplin Belajar

\begin{tabular}{|c|c|c|c|c|}
\hline Interval Skor & Kategori & Frekuensi & Presentase (\%) & Rata-Rata \\
\hline $82-100$ & Sangat Baik & 28 & $27 \%$ & \multirow{5}{*}{$\begin{array}{c}76 \\
\text { (Baik) }\end{array}$} \\
\hline $63-81$ & Baik & 71 & $69 \%$ & \\
\hline $44-62$ & Sedang & 4 & $4 \%$ & \\
\hline $25-43$ & Kurang & 0 & $0 \%$ & \\
\hline Jumlah & & 103 & $100 \%$ & \\
\hline
\end{tabular}

\section{Analisis Deskriptif Hasil Belajar IPS (Y)}

Data nilai hasil belajar IPS diperoleh melalui dokumentasi nilai PAS siswa semester ganjil. Berikut tabel kategori hasil belajar siswa kelas IV SDN Gugus Sadewa
Kecamatan Petanahan Kabupaten Kebumen : Tabel 3. Kategori Hasil Belajar IPS

\begin{tabular}{|c|c|c|c|c|}
\hline Kategori & Nilai & Frekuensi & Presentase & Rata-Rata \\
\hline Sangat Baik & $86-100$ & 22 & $21 \%$ & \multirow{5}{*}{$\begin{array}{c}81 \\
\text { (Baik) }\end{array}$} \\
\hline Baik & $71-85$ & 72 & $70 \%$ & \\
\hline Sedang & $56-70$ & 9 & $9 \%$ & \\
\hline Kurang & $\leq 55$ & 0 & $0 \%$ & \\
\hline \multicolumn{2}{|c|}{ Jumlah } & 103 & $100 \%$ & \\
\hline
\end{tabular}

Sumber: Data penelitian yang diolah menggunakan Microsoft Excel 2013

\section{Uji Linieritas}

Uji linieritas variabel kebiasaan belajar siswa dengan hasil belajar IPS diperoleh nilai.

\section{Uji Prasyarat Analisis \\ Uji Normalitas}

Uji normalitas digunakan peneliti untuk menentukan apakah data berdistribusi normal atau tidak. Pengujian dilakukan menggunakan analisis Kolmogrov-Smirnov Test. Berdasarkan hasil uji normalitas didapatkan nilai pada kebiasaan belajar sebesar 0,200, variabel disiplin belajar sebesar 0,200 dan variabel hasil belajar IPS sebesar 0,200 yang berarti bahwa nilai signifikansi pada masingmasing variabel mempunyai nilai yang lebih besar dari 0,05 , dengan demikian dapat disimpulkan bahwa ketiga variabel tersebut berdistribusi normal antara kebiasaan belajar dengan hasil belajar IPS siswa dinyatakan linier. Sedangkan uji linieritas variabel disiplin belajar dengan hasil belajar IPS diperoleh nilai signifikansi Deviation from Linearity 0,66 > 0,05 maka dapat disimpulkan bahwa hubungan antara disiplin belajar dengan hasil belajar IPS siswa dinyatakan linier. signifikansi Deviation from Linearity 0,052 > 0,05 maka dapat disimpulkan bahwa hubungan

\section{Uji Multikolinieritas}

Berdasarkan hasil perhitungan diperoleh bahwa variabel kebiasaan belajar dan disiplin belajar memiliki nilai Tolerance sebesar 0,365 > 0,1 dan nilai Variance Inflation Factor (VIF) sebesar $2,737<10$. Jadi, dapat disimpulkan bahwa dalam model regresi tidak ada masalah multikolinieritas antar variabel bebas.

\section{Analisis Hipotesis}

Analisis hipotesis menggunakan analisis korelasi sederhana, analisis korelasi ganda, uji $\mathrm{F}$ (signifikansi), dan uji koefisien determinasi.

\section{Hubungan Kebiasaan Belajar dengan Hasil Belajar IPS}

Uji korelasi sederhana dalam penelitian ini menggunakan uji korelasi product moment dengan 
bantuan program SPSS versi 22. Hasil perhitungan dapat dilihat pada tabel

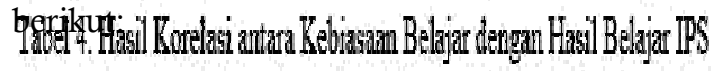

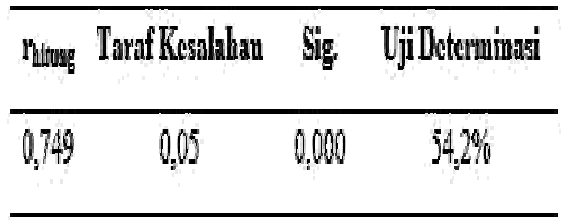

Tabel 4 menunjukkan hasil bahwa uji korelasi kebiasaan belajar dengan hasil belajar IPS siswa diperoleh hasil bahwa nilai rhitung lebih besar dari rtabel yaitu 0,749>0,195, sehingga Ha1 diterima, tanda positif pada rhitung yaitu 0,749 menunjukkan bahwa hubungan yang terjadi adalah positif atau searah, artinya semakin baik kebiasaan belajar maka semakin baik pula hasil belajar IPS siswa. Nilai 0,749 menunjukkan besarnya koefisien korelasi termasuk kriteria kuat yaitu berada pada rentang 0,60 - 0,799. Pada taraf signifikansi $5 \%$, didapatkan nilai signifikansi $0,000(0,000<0,05)$ sehingga korelasi dikatakan signifikan dan berlaku untuk populasi. Hasil perhitungan koefisien determinasi, diperoleh kontribusi kebiasaan belajar dengan hasil belajar IPS siswa sebesar 54,2\% sedangkan sisanya $45,8 \%$ dipengaruhi oleh faktor lain.

Berdasarkan perhitungan tersebut dapat disimpulkan bahwa terdapat hubungan yang positif dan signifikan antara kebiasaan belajar dengan hasil belajar IPS Siswa Kelas IV SDN Gugus Sadewa Kecamatan Petanahan Kabupaten Kebumen. Artinya, kebiasaan belajar siswa memiliki kontribusi dalam meningkatkan hasil belajar IPS. Siswa yang memiliki kebiasaan belajar yang baik dapat lebih mudah dalam menguasai materi IPS, lebih tertib dalam belajar, dan menjadi lebih aktif dalam pembelajaran sehingga hasil belajar IPS yang diperolehpun semakin meningkat, dengan kata lain semakin baik kebiasaan belajar siswa maka akan semakin baik pula hasil belajar IPS yang diperoleh dan sebaliknya.

\section{Hubungan Disiplin Belajar dengan Hasil Belajar IPS}

Uji korelasi sederhana dalam penelitian ini menggunakan uji korelasi product moment dengan bantuan program SPSS versi 22. Hasil perhitungan dapat dilihat pada tabel berikut:

\section{Tabel 5 Hasil Uji Korelasi Disiplin Belaiar dengan Hasil Belajer PS $r_{\text {litumg }}$ Taraf Kesalahan Sig. TjiDeterminasi}

\begin{tabular}{|c|c|c|c|}
\hline 0,777 & 0,05 & 0,000 & $57,0 \%$ \\
\hline
\end{tabular}

Tabel 5 menunjukkan hasil bahwa uji korelasi kebiasaan belajar dengan hasil belajar IPS siswa diperoleh hasil bahwa korelasi antara disiplin belajar dengan hasil belajar IPS siswa didapat nilai rhitung lebih besar dari rtabel yaitu $0,777>0,195$, sehingga $\mathrm{Ha} 2$ diterima, tanda positif pada rhitung yaitu 0,777 menunjukkan bahwa hubungan yang terjadi adalah positif atau searah, artinya semakin baik disiplin belajar maka semakin baik pula hasil belajar IPS siswa. Nilai 0,777 menunjukkan besarnya koefisien korelasi termasuk kriteria kuat yaitu berada pada rentang 0,60 - 0,799. Pada taraf signifikansi 5\%, didapatkan nilai signifikansi $0,000 \quad(0,000<0,05)$ sehingga korelasi dikatakan signifikan dan berlaku untuk populasi. Hasil perhitungan koefisien determinasi diperoleh kontribusi disiplin belajar dengan hasil belajar IPS sebesar $57,6 \%$ sedangkan sisanya $42,4 \%$ dipengaruhi oleh faktor lain.

Berdasarkan perhitungan tersebut dapat disimpulkan bahwa terdapat hubungan yang positif dan signifikan antara disiplin belajar dengan hasil belajar IPS siswa kelas IV SDN Gugus Sadewa Kecamatan Petanahan Kabupaten Kebumen. Artinya disiplin belajar siswa memiliki kontribusi dalam meningkatkan hasil belajar IPS. Siswa yang memiliki disiplin yang baik dapat lebih berkembang. Ketika siswa mendapatkan tugas muatan IPS, maka siswa akan berinisiatif dan memiliki kepercayaan diri dalam mengerjakan tugas-tugasnya serta bertanggung jawab terhadap apa yang dilakukannya. Maka, semakin baik disiplin belajar siswa maka akan semakin baik pula hasil belajar IPS yang diperoleh dan sebaliknya.

\section{Hubungan Kebiasaan Belajar dan Disiplin Belajar dengan Hasil Belajar Bahasa IPS}

Uji korelasi dalam penelitian ini menggunakan analisis korelasi ganda dengan bantuan program SPSS versi 22. Hasil perhitungan dapat dilihat pada tabel berikut:

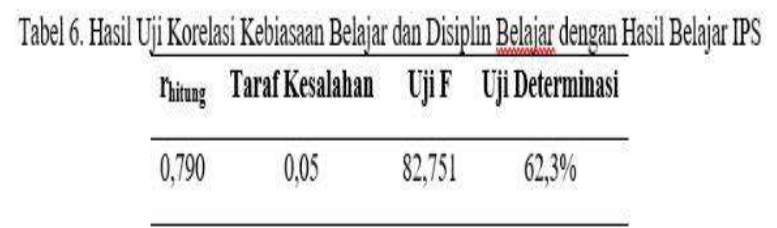

Tabel 6 menunjukkan hasil bahwa korelasi kebiasaan belajar dan disiplin belajar secara bersama-sama dengan hasil belajar IPS siswa didapat nilai rhitung lebih besar dari rtabel yaitu 0,790>0,195, sehingga Ha3 diterima, tanda positif pada rhitung yaitu 0,790 menunjukkan bahwa hubungan yang terjadi adalah positif atau searah, artinya semakin baik kebiasaan belajar dan disiplin belajar maka semakin meningkat pula hasil belajar IPS siswa. Nilai 0,790 menunjukkan besarnya koefisien korelasi termasuk dalam kriteria kuat yaitu berada pada rentang 0,60 - 0,799. Pada uji 
signifikansi, diketahui hasil nilai Fhitung lebih besar dari Ftabel yaitu 82,751 > 3,09, artinya

korelasi dikatakan signifikan dan dapat diberlakukan untuk seluruh populasi. Hasil perhitungan koefisien determinasi, diperoleh kontribusi kebiasaan belajar dan disiplin belajar dengan hasil belajar IPS sebesar 62,3\% sedangkan sisanya $37,7 \%$ dipengaruhi oleh faktor lain.

Berdasarkan hasil penelitian ini dapat disimpulkan bahwa terdapat hubungan yang positif dan signifikan antara kebiasaan belajar dan disiplin belajar secara bersama-sama dengan hasil belajar IPS siswa kelas IV SDN Gugus Sadewa Kecamatan Petanahan Kabupaten Kebumen. Kebiasaan belajar dan disiplin belajar merupakan faktor yang mempengaruhi hasil belajar IPS. Adanya kebiasaan belajar yang baik serta didukung oleh disiplin yang baik dalam pembelajaran IPS, maka hasil belajar IPS semakin baik pula.

\section{SIMPULAN}

Berdasarkan hasil penelitian dan pembahasan, maka dapat disimpulkan bahwa terdapat hubungan yang positif dan signifikan antara kebiasaan belajar dengan hasil belajar IPS Siswa Kelas IV SDN Gugus Sadewa Kecamatan Petanahan Kabupaten Kebumen, dengan rhitung lebih besar dari rtabel yaitu $0,749>0,195$ dalam kategori kuat serta berkontribusi sebesar 54,2\%, terdapat hubungan yang positif dan signifikan antara disiplin belajar dengan hasil belajar IPS Siswa Kelas IV SDN Gugus Sadewa Kecamatan Petanahan Kabupaten Kebumen, dengan rhitung lebih besar dari rtabel yaitu 0,777 > 0,195 dan termasuk kategori kuat serta berkontribusi sebesar $57,6 \%$, serta terdapat hubungan yang positif dan signifikan kebiasaan belajar dan disiplin belajar secara bersamasama dengan hasil belajar IPS siswa kelas IV SDN Gugus Sadewa Kecamatan Petanahan Kabupaten Kebumen, dengan rhitung lebih besar dari rtabel yaitu 0,790 >0,195 termasuk kategori kuat dan Fhitung lebih besar dari Ftabel yaitu $82,751>3,09$ serta berkontribusi sebesar 62,3\%.

\section{UCAPAN TERIMA KASIH}

Ucapan terima kasih disampaikan kepada: Dr. Drs. Ali Sunarso, M.Pd. selaku dosen pembimbing, Dra. Sumilah, M.Pd. selaku Mitra Bestari I, Drs. H. A. Zaenal Abidin, M.Pd. selaku Mitra Bestari II yang telah memberikan bimbingan dan masukan dalam penyusunan manuskrip.

\section{DAFTAR PUSTAKA}

Ashif Firmansyah, Dimas. (2019). Pengaruh lingkungan dan kedisiplinan belajar terhadap hasil belajar IPS kelas V SDN gugus kartini Kecamatan Dukuhwatu Kabupaten Tegal.

Daryanto. (2013). Pendidikan karakter di sekolah. Yogyakarta: Gaya Media.

Desmita. (2014). Psikologi perkembangan peserta didik. Bandung: Remaja Rosdakarya.

Dewi,D. P., dkk. Study habits of students achievement at SDN 95 Pekanbaru. Jurnal Pendidikan Guru Sekolah Dasar: 1-13

Njoroge, P. M., dkk. (2014). Discipline as a factor in academic performance in Kenya. Journal of Educational and Social Research. 4(1):

Ogwu, E. (2016). The native cultures on student discipline in school, Nigeria. 4(2).195-204 Peine, A., dkk. 2016. Self-direct learning can outperform direct instruction in the course of a modern German medical curriculum-result of a mixed trial. $B M C$ Medical Education. 16:158 DOI 10.1186/s12909- 016-0679-0.

Peraturan Menteri Pendidikan dan Kebudayaan Nomor 23 Tahun 2016 tentang Standar Penilaian Pendidikan. Jakarta: Depdiknas. 